\title{
Developing Innovation Activity of Industrial Enterprises Against the Background of Digitalization of the World Economy
}

\author{
Olga Nikulina \\ Department of World Economy and Management \\ Kuban State University \\ Krasnodar, Russia \\ E-mail: Olgafinans@mail.ru \\ Anastasia Perova \\ Department of World Economy and Management \\ Kuban State University \\ Krasnodar, Russia
}

\author{
Liudmila Ponomarenko \\ Department of World Economy and Management \\ Kuban State University \\ Krasnodar, Russia \\ Vladimir Pokul \\ Department of World Economy and Management \\ Kuban State University \\ Krasnodar, Russia
}

\begin{abstract}
The article discloses the main directions for developing innovation activity of industrial enterprises under the conditions of digitalization of the world economy. It has proven to be necessary to elaborate effective mechanisms for managing innovation activity of industrial enterprises in making the transition to the fourth industrial revolution, at the core of which are digital technologies providing for the advancement of the world economy digitalization processes. The substantiation is given to the methodological approaches to studying the patterns in the formation of a mechanism for managing innovative activity of industrial enterprises against the background of the economy digitalization with the synthesis of the Theory of the Firm and application of systematic approach, thereby disclosing their role and significance as agents and object of the digital economy. The analysis of the current situation in the area of boosting digitalization processes in the world economy has allowed us to assess the prospects and directions for development of innovative activity of industrial enterprises and make the case for defining the strategic trajectories of the development. There have been suggested strategic trajectories for developing innovative activity of industrial enterprises with regard to the benefits and drawbacks of the world economy digitalization.
\end{abstract}

Keywords-economy digitalization; development of innovation activity; industrial enterprises; the 4th industrial revolution; strategic trajectories of development

\section{INTRODUCTION}

In modern conditions of the world economy digitalization, developing innovation activity of industrial enterprises takes on special significance for enhancing the competitiveness of the national economy. Today, at the bottom of the digitalization process-formation there are innovations produced as a result of realization of innovation activity by modern companies and, in the first place, by industrial enterprises. At the same time, innovation activity of these very industrial enterprises is, in its turn, exposed to the effects of digitalization processes, which not only bring digital technologies to the activities of the companies, but also change the system of economic relations. This being said, the core competence of industrial enterprises starts to be the innovation activity, the result of which is the practical implementation of innovations providing for the formation of the digital economy. The realization of this competence places new demands on the content, organization, forms and methods of managing innovative activities performed at the industrial enterprises in the context of making the transition to the 4th industrial revolution, which leads to a qualitative transformation of social and economic relations between all participants in the innovation process. [1]

\section{The Methodology of Studying the Mechanism} FOR MANAGING INNOVATIVE DEVELOPMENT OF INDUSTRIAL ENTERPRISES AGAINST THE BACKGROUND OF THE WORLD \section{ECONOMY DIGITALIZATION}

The transition to the 4th industrial revolution is based on digitalization of economic and production processes, which is due to the introduction of the artificial intelligence technologies, big data, the Internet of Things and the Internet of Values (valueweb) and robotics. [2] The digital transformation of industrial enterprises encompasses all innovative activities and essentially modifies the production process itself, if not the traditional production logic. Owing to the complexity and indeterminate nature of innovation processes, there arises the need for introduction of new organizational and economic forms of production management enhancing access to innovations and requiring integration of all participants in the innovation process into a unified system. [3] One of the main results of this process starts to be the formation of principally-new business models ensuring the active implementation of digital technologies in 
development of industrial enterprises have derived the whole range of conceptions, each of which focuses on studying a specific aspect of the problem but does not provide for the systematic perception and overcoming thereof. [4] The most adequate way for solving this task is conceptualizing of the analyzed phenomenon on the bedrock of the systematic approach, inasmuch as innovative activities of industrial enterprises represent a special form of economic activity of business entities, different snapshots of which allow for identifying and studying the complete set of elements and relations between the participants in the digitalization process.

Studying innovative activities of industrial enterprises as being the key actors in the digitalization process implies the identification of their role and place in the development of the national economy, which requires that they be considered, on the one hand, as agents of the digital economy defining the main trends for its development based on their fulfilling the functions of a commissioner, a developer, a producer, an expert, a consumer and a promoter of digital technologies, and, on the other hand, as objects of the digital economy, the innovative activity of which is influenced by digital technologies, thus ensuring the high level of productivity, effectiveness and quality of all performed business processes.

The complexity and indeterminate nature of the problem of the economy digitalization by the virtue of the innovative 
LEVELS OF MANAGEMENT OF INNOVATIVE DEVELOPMENT OF INDUSTRIAL ENTERPRISES UNDER THE CONDITIONS OF THE DIGITALIZATION OF ECONOMY

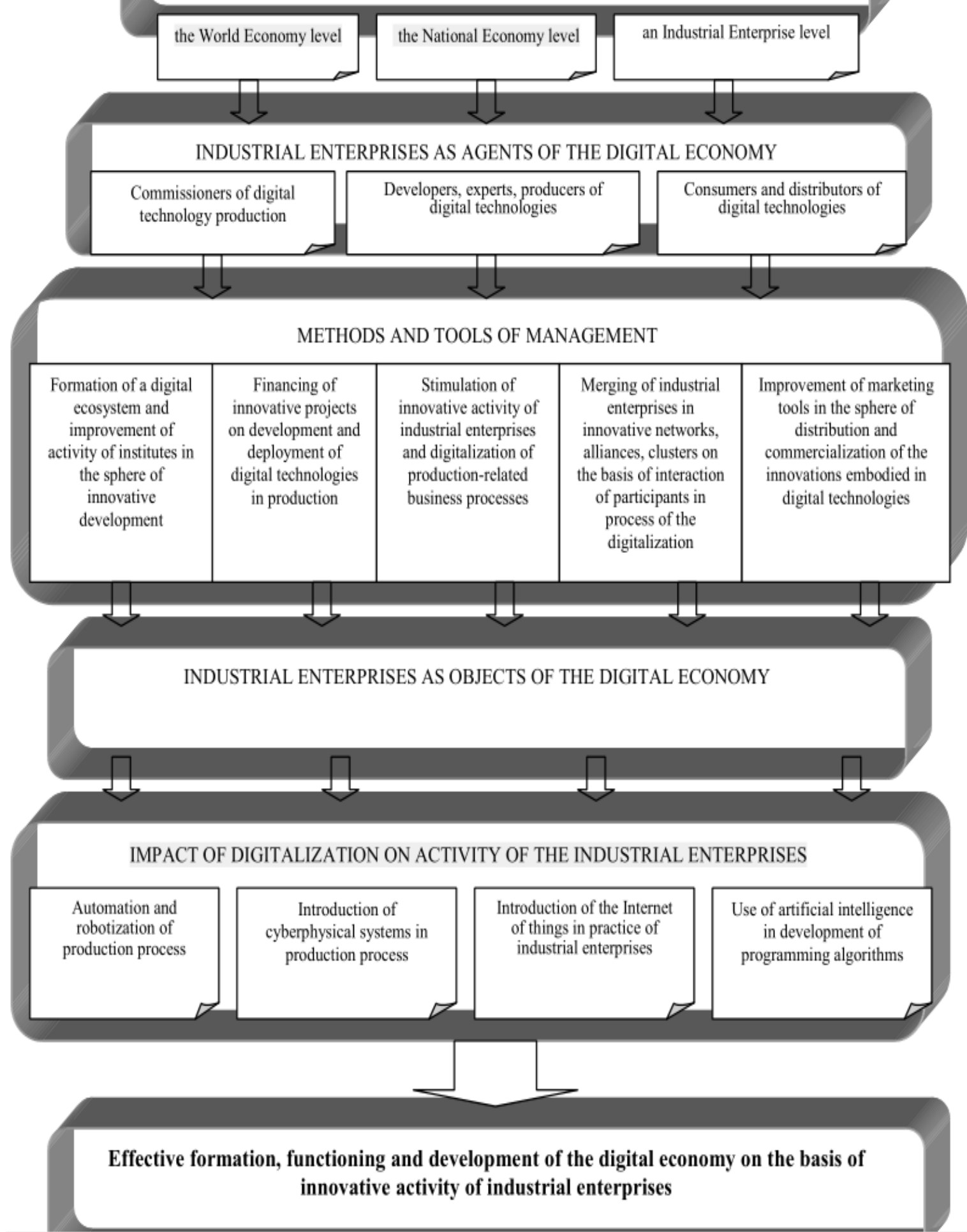

Fig. 1. Mechanism of management of innovative development of industrial enterprises under the conditions of digitalization of economy (developed by the authors).

While becoming agents in economic relations that undergo significant changes in the context of the economy digitalization, the industrial enterprises should form a management mechanism ensuring the effectiveness of their 
innovation activity, the competitiveness and an advantageous position in both domestic and foreign markets. Management as an uninterrupted process of influencing the management object with the purpose of achieving optimal results implies development and incorporation of such digital technologies in the practices of industrial enterprises as to ensure the acceleration of their production-related business processes by the devices of automation and robotization, as well as by means of the refinement of control system based on implementation of the Internet of Things and application of artificial intelligence in developing software algorithms.

\section{THE ANALYSIS OF IMPACT PRODUCED BY THE}

WORLD ECONOMY DIGITALIZATION ON THE DEVELOPMENT OF INNOVATION ACTIVITY OBSERVED AT INDUSTRIAL

\section{ENTERPRISES}

Analyzing the situation created in the area of digitalization process development in the world economy allows us to assess the scope of the implemented measures and levels of financing allocated for new lines of investment activities taken by the industrial companies providing for the early transition to the digital technologies. As estimated by experts, by 2025 , the size of digital economy will increase from $17.1 \%$ up to the $24.3 \%$ level of world GDP. [5] For comparison, by 2025 , the planned growth of Russia's digital economy is expected to increase from $3.6 \%$ to the $5 \%$ level of GDP or, in absolute terms, by RUB 9.6 trillion, which is approximately equal to USD 157 billion. [6] Already in 2018, the Chinese economy has demonstrated growth to the $34.8 \%$ level amounting to USD 4.6 trillion, which has allowed the experts to forecast further development until the period 2025 at the $38 \%$ level of GDP amounting to USD 6-7 trillion. [7] The obtained data concerning the increase of share of the digital economy in GDP should be weighed against the expenditures for scientific researches and developments, that have been effected by the leading countries over the period 2016-2017 and are going to be effected during the planned period until 2025 (see "Table I").

TABLE I. COMPARISON OF THE DIGITAL ECONOMY'S CONTRIBUTION TO GDP OF THE LEADING COUNTRIES WITH THEIR EXPENDITURES FOR SCIENTIFIC RESEARCHES AND DEVELOPMENTS, WHICH HAVE BEEN TAKEN AS A BASIS FOR THE DIGITAL ECONOMY FORMATION, OVER THE PERIOD $2016-2017$ AND THE PlanNED PERIOD UNTIL 2025 [5] [6] [7] [8] [9] [10]

\begin{tabular}{|c|c|c|c|c|c|c|c|c|}
\hline \multirow[t]{3}{*}{ Country } & \multicolumn{6}{|c|}{ Share of digital economy in GDP } & \multicolumn{2}{|c|}{$\begin{array}{c}\text { Expenditures, } \\
\$ \text { tn. }\end{array}$} \\
\hline & \multicolumn{2}{|l|}{2016} & \multicolumn{2}{|l|}{2017} & \multicolumn{2}{|l|}{2025} & 2016 & 2017 \\
\hline & $\%$ of GDP & $\$$ tn. & $\%$ of GDP & $\$$ tn. & $\%$ of GDP & $\$$ tn. & $\%$ of GDP & $\%$ of GDP \\
\hline USA & 5.4 & 1.2 & 7.0 & 1.35 & 10.9 & 2.3 & 2.8 & 2.6 \\
\hline China & 6.9 & 3.2 & 20.3 & 3.9 & 38.0 & 7.0 & 2.1 & 2.4 \\
\hline Japan & 5.6 & - & 6.9 & 0.355 & - & - & 3.6 & 3.14 \\
\hline South Korea & 8.0 & - & 12.0 & 0.2 & - & - & 4.2 & 4.55 \\
\hline United Kingdom & 12.4 & - & 7.1 & 1.4 & - & - & - & - \\
\hline Germany & 4.0 & - & 6.3 & 1.1 & - & - & 2.9 & 3.0 \\
\hline Russia & 2.8 & - & 3.9 & 0.103 & 5.0 & 0.157 & 1.1 & 3.6 \\
\hline World economy & 15.5 & 11.5 & 17.1 & 12.9 & 24.3 & 23.0 & - & - \\
\hline
\end{tabular}

${ }^{\text {a. }}$ Source: compiled by the authors according to figures from [5], [6], [7], [8], [9], [10]

The data presented in "Table I" allow for weighing the obtained results of the digital economy development against the effected expenditures for conduction of scientific researches and developments. Practically all countries effect expenditures for carrying out the scientific researches and developments underlying creation of digital technologies, in the size not less than $50 \%$ of the obtained results. The exception is China, where the share of the digital economy in GDP is significantly higher than the volume of expenditures for conduction of researches: in 2016, the digital economy's contribution to China's GDP was $6.9 \%$, whereas the expenditures amounted to $2.1 \%$; in 2017 , the digital economy's contribution was $20.3 \%$ and the expenditures for scientific researches and developments amounted to $2.4 \%$. In 2016, the USA had the share of the digital economy in GDP equal to $5.4 \%$ and the expenditures were effected in the amount of $2.8 \%$ of GDP, Japan, with the digital economy share indicated as $5.6 \%$, effected the expenditures in the amount of $3.6 \%$. Likewise, Germany had the indicator of the digital economy's contribution to GDP equal to $4.0 \%$ and the expenditure for conducting scientific researches and development amounted to $2.9 \%$. It should be noted that, in
2016, Russia also has effected expenditures for carrying out scientific researches and developments in the amount of $1.1 \%$ of GDP with the share of the digital economy in GDP at $2.8 \%$, however, already in 2017 , the expenditures for scientific researches in Russia have risen to a level of $3.6 \%$, which attests to the increase of the country's financial investments in the development of the digital economy. [11] To ensure the high level of competitiveness based on transition to the digital technologies in the Russian economy, a program has been developed and is being implemented entitled "Digital Economy of the Russian Federation," approved by Decree of the RF Government No.1632-r of July 28, 2017. "Table II" provides the data concerning the financing of the digital economy in Russia in accordance with the elaborated lines of development over the period 2019-2021. 
TABLE II. The Digital Economy Financing IN Russia over the Period 2019-2021 (IN BiLlion Rubles) [12]

\begin{tabular}{|c|c|c|c|c|c|}
\hline Lines of the program implementation & 2019 & 2020 & 2021 & Total & $\begin{array}{c}\text { Share in } \\
\text { costs } \\
\text { structure, \% }\end{array}$ \\
\hline Information infrastructure & 41.7 & 48 & 62 & 151.7 & 37.6 \\
\hline Digitalization of public administration & 29.2 & 31 & 41 & 101.2 & 25.1 \\
\hline Digital technologies and projects & 21.5 & 25.5 & 41.6 & 88.6 & 21.9 \\
\hline Human resource for the digital economy & 10.5 & 13.3 & 22.4 & 46.2 & 11.4 \\
\hline Information security & 4.8 & 5.6 & 4.9 & 15.3 & 3.8 \\
\hline Statutory regulation of the digital environment & 0.265 & 0.265 & 0.265 & 0.795 & 0.2 \\
\hline Total funding for the program & 107.965 & 123.665 & 172.165 & 403.795 & 100.0 \\
\hline
\end{tabular}

The major portion in overall funding allocated to the digital economy in Russia are the costs for the establishment of information infrastructure - 37.6\% ("Table II"), whereas the share of the costs for digital technologies and projects is $21.9 \%$. Mention should be made of stable growth of financing the major areas of the digital economy in Russia, which is planned to be realized for the period 2019-2021. The similar situation with increased funding of expenditures for the development of the digital economy is observed also in OECD countries. According to OECD statistics [13], during the period of the post-crisis development of the world economy in 2016-2018 there has been observed the growth of spending for researches and development in percentage terms of GDP by OECD countries from $2.34 \%$ in 2017 to the $2.37 \%$ level in 2018 , besides the state funding of R\&D work in these countries has grown by $2.1 \%$ in 2018 in real terms of the allocated budgetary funds. In OECD countries, according to statistical data [13], there has been a growth in the commercial sector's activity in the sphere of R\&D, which demonstrates the interest of the enterprises in boosting innovation activity, providing them with the possibility of transition to digital format. Unfortunately, the commercial sector in Russia is not very active in financing innovative projects allowing for the development and implementation of digital technologies. In many respects it can be explained by the insufficiency of financial resources and lack of interest on the part of business in boosting innovation activity, which is highly-risky, costly and does not deliver a guaranteed result in the short term. However, it's the innovation activity of industrial enterprises that provides an opportunity for transition to digital technologies.

According to expert opinion, a nucleus of the digital economy is intended to be the information-andcommunication technology sector along with content-andmass media sector. [14] It should be noted, that the role and significance of these sectors as being a nucleus for the formation of innovative economy are important indeed, but the balanced development of the economy is to be ensured by the industrial enterprises, the innovation activity of which, on the one hand, forms the demand for digital technologies and, on the other hand, creates the innovations that are necessary for the establishment and boosting of the digital economy (for example, industrial robots, innovative equipment in the form of electronic chips and sensors, etc.). The statistical data from sources [15], [16] reflect two major trends characterizing the degree of innovative development of the Russian economy: on the one part, the insufficient level of innovative activity shown by Russian companies, and, on the other part, - growth in the volume of domestic expenditures (see "Table III").

TABLE III. THE DYNAMICS OF INDICATORS CHARACTERIZING THE INNOVATION ACTIVITY OF RUSSIAN ENTERPRISES AND THE VOLUME OF DOMESTIC EXPENDITURES FOR SCIENTIFIC RESEARCHES AND DEVELOPMENTS FOR THE PERIOD 2014-2017 [15] [16]

\begin{tabular}{|c|c|c|c|c|c|}
\hline Indicators & 2014 & 2015 & 2016 & 2017 & $2017 / 2014$ \\
\hline Value of innovative goods, works and services, in billion rubles & 3037.4 & 3258.3 & 3723.7 & 4167.0 & 1.37 \\
\hline $\begin{array}{l}\text { Specific weight of innovative goods, works and services in the total } \\
\text { volume of delivered goods, works and services, } \%\end{array}$ & 8.2 & 7.9 & 8.4 & 7.2 & 0.88 \\
\hline Expenditures for technological innovations, in billion rubles & 762.7 & 735.8 & 777.5 & 1405.0 & 1.84 \\
\hline $\begin{array}{l}\text { Relative share of expenditures for technological innovations in the } \\
\text { total volume of shipped goods, delivered works and services, } \%\end{array}$ & 2.1 & 1.8 & 1.8 & 2.4 & 1.14 \\
\hline $\begin{array}{l}\text { Domestic expenditures for scientific researches and developments, in } \\
\text { billion rubles }\end{array}$ & 847.5 & 914.7 & 943.8 & 1019.2 & 1.20 \\
\hline $\begin{array}{l}\text { Domestic expenditures for scientific researches and developments, as } \\
\text { a percentage of GDP, } \%\end{array}$ & 1.07 & 1.10 & 1.10 & 1.11 & 1.04 \\
\hline
\end{tabular}

Source: compiled by the authors according to figures from [15], [16]

The data presented in "Table III" show positive dynamics, however, they reflect a decrease in the specific weight of innovative goods, works and services in the total volume of delivered goods, works and services in 2017 by $12 \%$, as compared to the crisis period beginning in 2014. [16] In terms of development of the digital economy, it is necessary to ensure the growth of this indicator, considering that, in the future, the release of a wider range of industrial equipment and software solutions will be required for making the transition to digital technologies. [17] According to expert estimates, the size of technology market for digital production enterprises is projected at USD 700 billion in 
2020 and, by 2025, - at USD 3 trillion. [18] In this regard, it should be noted that to enhance the level of innovation activity displayed by Russian industrial companies, it is not sufficient to use only one way of stimulating through an increase in financing of scientific researches and developments. It is expedient to develop integrative and networked forms of interaction between innovative companies, unite the efforts of the state, science and business in the area of innovative developments related to production and implementation of digital technologies and establish a digital ecosystem. Industrial enterprises as agents of the digital economy show these days a great demand for creation of an information infrastructure and special conditions for boosting innovation activity against the background of the economy digitalization, independently develop ways and stages of digitalizing their innovative activities, implement end-to-end digital technologies in their production processes. Digital technologies produce a significant impact on the development of innovative activities conducted by industrial enterprises as management objects, while contributing to unleashing and realization of their innovation potential. It therefore seems necessary to determine strategic trajectories for the development of innovative activities conducted by industrial enterprises under the conditions of the economy digitalization with account of the speedy development of all digital technologies in the world economy and qualitative changes in all business processes as a result of the digitalization. [19]

\section{THE STRATEGIC TRAJECTORIES FOR THE DEVELOPMENT OF INNOVATIVE ACTIVITIES CARRIED OUT BY INDUSTRIAL ENTERPRISES IN THE CONTEXT OF THE ECONOMY DIGITALIZATION}

The impact made by the digital economy on innovative activities of industrial enterprises leads to changing the strategic guidelines and passing to a qualitatively new development level. However, it should be emphasized that the economy digitalization produces both positive and negative effect on the activities of production companies, while simultaneously providing the enterprises with competitive advantages and creating specific barriers impeding the development of innovative activities, which results in the formation of drawbacks. "Table IV" presents the strategic trajectories for innovative development of industrial enterprises with account of benefits and drawbacks of the world economy digitalization.

TABLE IV. THE STRATEGIC TRAJECTORIES FOR INNOVATIVE DEVELOPMENT OF INDUSTRIAL ENTERPRISES WITH ACCOUNT OF ADVANTAGES AND DISADVANTAGES OF THE WORLD ECONOMY DIGITALIZATION

\begin{tabular}{|c|c|c|}
\hline $\begin{array}{c}\text { Advantages of the economy } \\
\text { digitalization in terms of development of } \\
\text { innovative activities of industrial } \\
\text { enterprises }\end{array}$ & $\begin{array}{c}\text { Disadvantages of the economy digitalization in } \\
\text { terms of development of innovative activities } \\
\text { of industrial enterprises }\end{array}$ & $\begin{array}{l}\text { Strategic trajectories for development of innovative } \\
\text { activities of industrial enterprises under the } \\
\text { conditions of the economy digitalization }\end{array}$ \\
\hline $\begin{array}{l}\text { Digitalization ensures the possibility of } \\
\text { automating all production-related business } \\
\text { processes by means of introduction of } \\
\text { digital technologies, robotization and } \\
\text { increases the effectiveness of monitoring } \\
\text { due to the implementation of technologies } \\
\text { associated with the industrial Internet of } \\
\text { things (IoT). }\end{array}$ & $\begin{array}{l}\text { Digitalization based on introduction of the } \\
\text { industrial Internet of things (IoT) necessitates the } \\
\text { transition to mass standardization, which leads to } \\
\text { the uniformity of production enterprises and, as a } \\
\text { concequence, contributes to market } \\
\text { monopolization by major companies. }\end{array}$ & $\begin{array}{l}\text { The strategy for boosting innovative activities based on } \\
\text { designing and applying new innovative products and } \\
\text { digital technologies will allow the industrial enterprises } \\
\text { to integrate into new digital sectors and markets with } \\
\text { high prospects for long-term growth and profitability. }\end{array}$ \\
\hline $\begin{array}{l}\text { Digitalization allows the industrial } \\
\text { companies to considerably reduce } \\
\text { transaction costs in the process of active } \\
\text { implementation of digital technologies. }\end{array}$ & $\begin{array}{l}\text { At the initial stage of its development, } \\
\text { digitalization is a costly process for industrial } \\
\text { enterprises resulting in growth of prices for } \\
\text { innovative projects and technologies. }\end{array}$ & $\begin{array}{l}\text { The strategy for providing financial incentives for } \\
\text { digitalization of industrial enterprises on the part of the } \\
\text { state on account of financing innovative projects, } \\
\text { provision of grants, subsidies and tax exemptions will } \\
\text { allow the industrial enterprises to get financial support } \\
\text { for conduction of scientific researches and } \\
\text { developments with the purpose of creating end-to-end } \\
\text { digital technologies. }\end{array}$ \\
\hline $\begin{array}{l}\text { Digitalization enables the industrial } \\
\text { enterprises to increase the effectiveness of } \\
\text { innovative activities on the account of } \\
\text { introducing new digital technologies and } \\
\text { emergence of new business models. }\end{array}$ & $\begin{array}{l}\text { Digitalization compels the industrial enterprises } \\
\text { to constantly work out new mechanisms for } \\
\text { managing innovative activities resulting in } \\
\text { continuous changes and transformations, job } \\
\text { losses, revision of all traditional management } \\
\text { methods and tools. }\end{array}$ & $\begin{array}{l}\text { The strategy for development of competitive advantages } \\
\text { will allow the industrial enterprises to gain leverage in } \\
\text { terms of costs of production and marketing, } \\
\text { differentiation of innovative products (service), focusing } \\
\text { on specific types of innovative activities providing for } \\
\text { creation and implementation of digital technologies. }\end{array}$ \\
\hline $\begin{array}{l}\text { Digitalization allows the industrial } \\
\text { enterprises to create new workplaces and } \\
\text { set forth the demand for new professions. }\end{array}$ & $\begin{array}{l}\text { Digitalization changes labor market, leads to } \\
\text { unemployment and forces the industrial } \\
\text { enterprises to spend financial resources on } \\
\text { personnel training and education. }\end{array}$ & $\begin{array}{l}\text { The strategy for encouraging the specialists gain new } \\
\text { knowledge and new competencies will allow the } \\
\text { industrial enterprises to resolve staffing issue in order to } \\
\text { introduce digital technologies in the production process. }\end{array}$ \\
\hline $\begin{array}{l}\text { Digitalization creates conditions for } \\
\text { implementation at industrial enterprises of } \\
\text { a software-information platform that is } \\
\text { configured based on a unified scheme for } \\
\text { presentation of the data concerning the } \\
\text { control over the product life-cycle-related } \\
\text { processes. }\end{array}$ & $\begin{array}{l}\text { The economy digitalization leads to the } \\
\text { transformation of traditional production } \\
\text { processes and is interlinked with technological } \\
\text { novelties and organizational changes, modifies } \\
\text { corporate culture at any industrial enterprise. }\end{array}$ & $\begin{array}{l}\text { The strategy for establishment of a digitalized industrial } \\
\text { enterprise should be based on a platform combining } \\
\text { automation, connectedness, security system and } \\
\text { analytics based on end-to-end integration of information } \\
\text { technologies, production and business process control } \\
\text { tools. }\end{array}$ \\
\hline
\end{tabular}


accounting and optimization of all business processes. [21] The major challenge of innovative activities is the industrialization of knowledge-consumptive digital technologies, their commercialization and market promotion that are associated with the necessity of indispensable digitalization of all economic operations performed at the enterprise in case of changing the production technology during the transition to a digital format. The innovative development of industrial enterprises presupposes not only the basic process for absorption of innovations under the economy digitalization conditions, but also the formation of a system of factors and conditions required for its successful realization in the digital space.

Thus, the determination of strategic trajectories for innovative development of industrial enterprises in the face of the world economy digitalization constitutes a prerequisite and a means of analyzing the world economy and the events occurring therein and substantiating the adopted solutions, forecasting, planning and managing the innovative processes and objects. It should be noted that the economy digitalization is a means of improving the effectiveness of innovative activities carried out at the industrial enterprises, the results of which determine the effective realization of the digital transformation of all business processes, and developing the innovative activities of the industrial enterprises, in its turn, allows the digital economy to reach a high-level of competitiveness.

\section{CONCLUSION}

As a result of the conducted study on the prospects and tracks of the innovation activity development at industrial enterprises under the conditions of the world economy digitalization, the following conclusions emerged:

Firstly, these days, the world economy digitalization prompts us to take a fresh look on the prospects of developing innovation activity of industrial enterprises enabling creation and implementation of digital technologies in all spheres of economic activities. When transitioning to the 4th industrial revolution (Industry 4.0), there can be observed a high level of digital upgrade reached by industrial enterprises and, hence, a high level of investments and risks related thereto. There is a need to elaborate effective mechanisms for managing innovative development of industrial enterprises capable of ensuring a high-level competitiveness of the global and national economies under the conditions of transitioning to a digital format based on developing knowledge, competencies and digital technologies.

Secondly, the key factor responsible for modern development of innovative activities performed by industrial enterprises against the background of the world economy digitalization is now represented by technologies associated with artificial intelligence, big data, the Internet of Things and the Internet of Values, as well as robotics. These days it's very important to determine key positions to be taken by industrial enterprises in the specified areas in order to form strategic trajectories for developing the business, the successful innovation activity of which defines economic to the formation of control system based on implementation of digital technologies ensuring the effective monitoring, 
managing production and business processes. The proposed strategic trajectories that are necessary for the development of innovation activity of industrial enterprises with account of the impact made by the world economy digitalization processes allow for elaborating new models and mechanisms for managing innovative development of Russian economy in proceeding to the 4 th industrial revolution.

\section{REFERENCES} experts, consumers and distributors of digital technologies. In this regard, consideration needs to be given to the fact that digitalization promotes creation of principally-new technologies, forms a common information space, makes the participants in the innovation process join together in strategic alliances and networks, stimulates industrial enterprises to carry out scientific researches and developments. This creates favorable conditions for the transition towards the use digital technologies in all spheres of economic activities. Simultaneously, there occurs transformation of production-related business processes inside the industrial enterprises, which act as an object of the digital economy and, subjected by its influence, elaborate the strategic trajectories for the development of innovative activities based on incorporation of digital technologies in the production process.

Fourthly, the results of analyzing the current situation in the area of developing digitalization processes in the world economy allow for assessing the rapid growth of financial inputs into the digital technologies of all countries involved in the digitalization race. Comparison of the share of the digital economy in GDP of leading countries and their expenditures for scientific researches and developments has demonstrated the common trend for the increase in spending on scientific researches and developments, and, notably, in OECD countries there has been observed a high-level of interest taken by commercial sector in relation to R\&D. In Russia, the key role is played by the state-provided financial support in the area of developing innovative activities carried out by industrial enterprises under the conditions of transitioning to the economy digitalization. Russian companies should scale up their innovation activity and build up their digital capacities more intensively in order to enable the national economy to reach a high-level competitiveness in the era of rapid development of the market of technologies for the digitalized production enterprises.

Fifthly, moving from the stage of theoretical conceptualization of the problem towards specifying its solution in practice implies the formation of strategic trajectories of developing the innovative activities to be carried out by industrial enterprises in the face of the world economy digitalization based on the establishment of an effective system for stimulating the enterprises' innovation activity, the use of new innovative products and digital technologies, the financial support of innovation projects aimed at digitalization of production process, training of highly-qualified specialists for the digital economy and creating of a platform combining automation, connectedness, security system and analytics based on end-to-end integration of information technologies and tools for
[1] Mark Anthony Robben. A study of innovative behavior in high 2018. 110 p.

[2] Economy and industry development trends in the context of digitalization/ edited by A.V. Babkina, PhD in Economics, Professor. - SPb.: Publishing house of Polytechnic University, 2017. - 658 p.

[3] Toomsalu, L., Tolmacheva, S., Vlasov, A., and Chernova, V. (2019). Determinants of innovations in small and medium enterprises: a european and international experience. // Terra Economicus, 2019, 17(2), pp.112-123. DOI: 10.23683/2073-6606-2019-17-2-112-123

[4] Angelo Fusari. A New Economics for Modern Dynamic Economies: Innovation, Uncertainty and Entrepreneurship. Taylor and Francis Inc. Taylor \& Francis. 2016. 276 p. Huawei и Oxford Economics. URL: spillover/files/gci_digital_spillover.pdf

[6] Titarenko E. Digital economy growth is foreseen. URL: https://www.comnews.ru/content/107558/2017-07-06/cifrovoyekonomike-prorochat-rost

[7] Kononov I. The participants in Eurasian integration are highlyresourced for establishment of the digital economy. "Economy and Life.” 05/07/2019.URL: https://www.eg-online.ru/article/402491/

[8] The Digital Russia: new reality. Digital McKinsey. URL: http://www.tadviser.ru/images/c/c2/Digital-Russia-report.pdf

[9] Presentation of "Report on the Digital Economy 2019" UNCTAD. United Nations Information Center in Moscow. URL:http://www.unic.ru/activity/prezentatsiya-doklada-o-tsifrovoiekonomike-2019-yunktad.

[10] The Digital Economy: 2019: concise collected statistics/ G.I Abdrakhmanova, K.O. Vishnevsky, L.M. Gokhberg et al.; National Research University "Higher School of Economics." - M.: NRU HSE 2019. - 96 p.

[11] Monitoring Global Digitalization Trends. Rostelecom. - P. 20. URL: https://www.company.rt.ru/projects/digital_trends/2018.pdf

[12] Funding for national project "Digital Economy." [Electronic resource].

URL:http://www.tadviser.ru/index.php/Статья:Финансирование пр ограммы_Цифровая_экономика\#.D0.A1.D0.BE.D0.BA.D1.80.D̄0 B0.D1.89.D0.B5.D0.BD.D0.B8.D0.B5_.D1.84.D0.B8.D0.BD.D0.B0. D0.BD.D1.81.D0.B8.D1.80.D0.BE.D0.B2.D0.B0.D0.BD.D0.B8.D1. 8F_.D0.BF.D1.80.D0.BE.D0.B3.D1.80.D0.B0.D0.BC.D0.BC.D1.8B C2.AB.D0.A6.D0.B8.D1.84.D1.80.D0.BE.D0.B2.D0.B0.D1.8F .D 1.8D.D0.BA.D0.BE.D0.BD.D0.BE.D0.BC.D0.B8.D0.BA.D0.B0.C2. B2_2_.D1.80.D0.B0.D0.B7.D0.B0_.E2.80.94_.D0.B4.D0.BE_1.2C6 _.D1.82.D1.80.D0.BB.D0.BD_.D1.80.D1.83.D0.B1.D0.BB.D0.B5.D 0.B9

[13] Main Science and Technology Indicators, Volume 2018 Issue 1. OECD Publishing, Paris. URL: http://www.oecd.org/sti/msti.htm

[14] Digital Economy: global trends and practice of Russian business. Analytical report from Innovation Management Institute of NRU HSE. - $\quad$ pp. 12-17. URL: https://imi.hse.ru/data/2017/10/07/1159564192/!Цифровая\%20эконо мика\%20-

\%20глобальные\%20тренды\%20и\%20практика \%20российского\% 20бизнеса.pdf technology product development organizations. Taylor \& Francis

[5] Digital Spillover: Measuring the true impact of the digital economy. https://www.huawei.com/minisite/gci/en/digitalBB_.D0.B1.D0.BE.D0.BB.D0.B5.D0.B5_.D1.87.D0.B5.D0.BC_.D0. 
[15] Indicators of digital economy: 2018: brief statistical collection/ G.I. Abdrakhmanova, K.O. Vishnevsky, G.L. Volkova, L.M. Gokhberg et al.; National Research University "Higher School of Economics." M.: NRU HSE, 2018. -268 p.

[16] Russia in Figures. 2019: concise statistical handbook/Rosstat-M., 2019 - 549 p.

[17] Minashkin V.G., Prokhorov P.E. Statistical analysis of the use of digital technologies in organizations: regional aspect. "Statistics and Economy." 2018; 15(5). PP. 51-62. https://doi.org/10.21686/25003925-2018-5-51-62.

[18] Chakravorti B., Chaturvedi R. Sh. Digital Planet 2017: How Competitiveness and Trust in Digital Economies Vary Across the World. Medford: The Fletcher school Tufts university, 2017. $70 \mathrm{p}$. [Electronic resource]. URL: https://sites.tufts.edu/digitalplanet/files/2017/05/Digital_Planet_2017 _FINAL.pdf

[19] Nicole Pfeffermann. Strategy and communication for innovation: Integrative perspectives on innovation in the digital economy. Springer International Publishing. Springer Nature. 2017. 424 p.

[20] Multi-sided platforms (MSPs) and sharing strategies in the digital economy: Emerging research and opportunities. IGI Global. 2018. $192 \mathrm{p}$.

[21] Dave Elder-Vass. Profit and gift in the digital economy. Cambridge University Press. 2016. 260 p. 